\title{
PRODUKSI ANTISERUM DAN KAJIAN SEROLOGI CHRYSANTHEMUM B CARLAVIRUS (CVB)
}

\author{
I G.R.M. Temaja ${ }^{1}$, G. Suastika ${ }^{2}$, S.H. Hidayat ${ }^{2} \&$ U. Kartosuwondo ${ }^{2}$
}

\begin{abstract}
Antiserum production and serological assay of Chrysanthemum B Carlavirus (CVB). Virus identification based on spesific reaction between antigen and antibody in serological assay has been widely applied as a tool for plant virus detection. The aims of this research is to produce antiserum of the CVB by guinea pig immunization using purified CVB of Cianjur isolate. The antiserum was used further for the serological test. Serological methods for detection of CVB were I-ELISA, TBIA, western blot and ISEM. The result showed that guinea pig immunization using $150 \mu \mathrm{g}$ of purified virus was able to produce $10.75 \mathrm{ml}$ of antiserum. The antiserum produced had high sensitivity for detection of CVB when examined by I-ELISA and TBIA. Besides its low cost, TBIA allows the samples to be blotted on the nitrocellulose membranes in the field and storage of the membranes for later processing in the laboratory. This feature makes it the metode of choice for large-scale CVB surveying.
\end{abstract}

Key words: Chrysanthemum B Carlavirus (CVB), chrysanthemum (Dendranthema grandiflora), antiserum

\section{PENDAHULUAN}

Chrysanthemum B Carlavirus (CVB) merupakan salah satu penyebab penyakit utama pada tanaman krisan (Dendranthema grandiflora Kitam.) menginduksi berbagai macam gejala. Belang dan pemucatan tulang daun yang sangat ringan adalah gejala yang paling umum (Hollings \& Stones, 1972; Verma et al., 2003). Beberapa varietas krisan terinfeksi menunjukkan penurunan kualitas bunga, terutama karena pada tanaman terinfeksi warna mahkota bunga terputusputus (pecah warna), mengalami distorsi dan berukuran lebih kecil dari normal. Kadang-kadang pada krisan terinfeksi CVB berkembang gejala garis nekrotik pada bunga, dan sering kali tanaman terinfeksi tidak menunjukkan gejala (symptomless).

CVB dapat ditularkan melalui inokulasi mekanik dan penyambungan, walaupun secara alami virus ini ditularkan secara non persisten oleh kutudaun Myzus persicae, Macrosiphum euphorbiae, Aulacorthum solani, Coloradoa rufomaculata dan Macrosiphoniella sanborni (Hollings \& Stones, 1972; Temaja, 2008). Penyebaran jarak jauh CVB terjadi terutama melalui bahan perbanyakan vegetatif tanaman. Hal inilah yang menyebabkan negara-negara pengimpor krisan menerapkan aturan ketat terhadap semua bahan tanaman krisan yaitu harus bebas virus.

Indonesia sebagai salah satu komunitas dunia, bila ingin produk krisannya diterima di pasar dunia, harus mengikuti aturan perdagangan internasional terutama perlakuan karantina tumbuhan. Sertifikasi bahan tanaman krisan bebas virus membutuhkan metode deteksi yang cepat dan akurat. Tantangan ini mendorong penelitian yang akan dilakukan mengarah pada penyediaan metode deteksi CVB yang diperlukan dan dapat diterapkan untuk pemenuhan kebutuhan sertifikasi. Sertifikasi yang didukung metode deteksi yang handal diharapkan dapat menyelamatkan ekspor krisan Indonesia. Metode deteksi yang digunakan harus memenuhi persyaratan sensitifitas, massal dan ekonomis. Dalam rangka memenuhi kriteria semacam itu maka dalam penelitian ini akan digunakan metode deteksi berbasis antiserum (serologi).

Teknik serologi merupakan salah satu cara deteksi dan identifikasi suatu patogen dalam suatu inang, yang memanfaatkan reaksi spesifik antara antigen dan antiserum (Crowther, 1995). Metode ini telah mengalami perkembangan yang sangat pesat dan aplikasinya di bidang penyakit tumbuhan sudah sangat umum digunakan, yaitu untuk mendeteksi suatu patogen

\footnotetext{
${ }^{1}$ Jurusan Agroekoteknologi, Fakultas Pertanian, Universitas Udayana, Jl. PB. Sudirman Denpasar 80232. E-mail: gederaimaya@yahoo.com

${ }^{2}$ Departemen Proteksi Tanaman, Fakultas Pertanian, Institut Pertanian Bogor,

Jl. Kamper, Kampus Darmaga, Bogor 16680
} 
khususnya virus dalam tanaman. Kegunaan yang lain dari uji serologi ini adalah menentukan konsentrasi virus dalam jaringan tumbuhan, mendeteksi virus tumbuhan dalam tubuh serangga vektor dan untuk mengetahui hubungan kekerabatan antar virus (Agrios, 1997). Deteksi dan identifikasi secara serologi sudah umum diaplikasikan untuk berbagai virus. Ada beberapa teknik deteksi virus yang berbasis serologi antara lain immunosorbent electron microscopy (ISEM) (Dykstra, 1992; Flegler et al., 1993), immunoflourescent staining (Hampton et al., 1990), gel double-diffusion test, dotblot immunobinding assay (DIBA), tissue-blot immunoassay (TBIA), Western blot (Harlow \& Lane, 1999; Lin et al., 1990), agarose gel presipitation test (AGPT) (Mahmood et al., 1997) dan enzyme linked immunosorbent assay (ELISA) (Harlow \& Lane, 1999; Kumari et al., 2006).

Keberhasilan dan ketelitian teknik serologi untuk mendeteksi dan mengidentifikasi virus sangat tergantung pada ketersediaan pereaksi diagnostik seperti antiserum dengan kualitas yang baik (Kumari et al., 2006). Untuk membuat antiserum atau antibodi dari suatu virus tumbuhan pada umumnya digunakan protein selubung partikel virus, dengan menginjeksikan virus murni ke tubuh hewan. Beberapa jenis hewan berdarah panas yang sering digunakan untuk memproduksi antibodi antara lain kelinci, marmut, ayam, mencit, domba dan kuda. Oleh sebab itu pada penelitian ini akan dilakukan kajian serologi CVB, meliputi produksi antiserum dan pengujian metode serologi untuk deteksi sampel.

Tujuan penelitian ini adalah untuk mengetahui sifat antigenik siapan murni CVB isolat Indonesia melalui immunisasi pada hewan mamalia dan menyediakan metode deteksi CVB berbasis antiserum yang dapat digunakan untuk keperluan sertifikasi bibit krisan bebas virus.

\section{METODE PENELITIAN}

Penelitian ini dilakukan dari bulan Oktober 2008 sampai April 2009, di Laboratorium Virologi dan rumah kaca Kebun Percobaan Cikabayan, Departemen Proteksi Tanaman, Fakultas Pertanian, IPB Bogor.

Penyiapan Antigen. Antigen yang akan dipakai pada produksi antiserum adalah virus murni CVB isolat Cianjur. Pembuatan virus murni memerlukan jaringan tanaman terinfeksi dalam jumlah besar. Sebagai inang perbanyakan CVB digunakan tanaman Nicotiana benthamiana. Tanaman umur tiga minggu diinokulasi secara mekanis dengan cairan perasan tanaman krisan terinfeksi CVB. Sampel daun terinfeksi digerus dan ditambahkan larutan bufer fosfat $0,01 \mathrm{M}, \mathrm{pH} 7,0(1: 5 \mathrm{~b} /$ v). Cairan perasan inokulum ini segera diinokulasikan ke bagian daun tanaman inang perbanyakan. Setelah 17 hari dari saat inokulasi, daun dan ranting tanaman dipanen. Metode pemurnian CVB dilakukan sesuai dengan prosedur dari Foster (1998).

Pembuatan Antiserum. Antiserum diproduksi dengan melakukan imunisasi dua ekor marmut jantan berumur sekitar 6 bulan. Imunisasi dilakukan dengan menginjeksikan virus murni isolat Cianjur beserta larutan adjuvant. Injeksi dilakukan di bawah kulit (sub cutaneous) 5 kali dengan interval waktu 2 minggu. Injeksi pertama dengan dosis $50 \mu \mathrm{g}$ virus murni yang ditambah complete adjuvant dengan perbandingan 1:1. Injeksi selanjutnya dengan dosis $25 \mu \mathrm{g}$ virus murni yang ditambah incomplete adjuvant dengan perbandingan 1:1. Sepuluh hari setelah penyuntikan terakhir, dilakukan panen darah dengan cara mengambil darah melalui jantung dan disembelih. Butir darah merah dibiarkan mengendap dan disimpan dalam suhu $4^{\circ} \mathrm{C}$ selama 12 jam. Cairan bening diambil dengan hati-hati kemudian disentrifugasi pada kecepatan $3.000 \mathrm{rpm}$ (rotor TMA5 , Tomy) selama 20 menit, selanjutnya antiserum yang dihasilkan (antiserum tidak diserap) dapat dimanfaatkan untuk pengujian serologi atau disimpan pada suhu $-20^{\circ} \mathrm{C}$ dengan ditambah sodium azide $1 \%$. Antiserum bisa langsung digunakan untuk pengujian serologi, dan untuk meningkatkan kualitas dilakukan penyerapan menggunakan cairan perasan tanaman Nicotiana benthamiana sehat serta pemurnian gamma-globulin menggunakan amonium sulfat. Konsentrasi antiserum semua jenis antiserum (tidak diserap, diserap dan murni) diukur berdasarkan nilai absorbansi 1,4 pada panjang gelombang $280 \mathrm{~nm}$ setara dengan konsentrasi $1 \mathrm{mg} \mathrm{ml}^{-1}$.

Penyerapan Antiserum. Penyerapan antiserum dilakukan berdasarkan metode Dijkstra \& de Jager (1998), yaitu antiserum diserap dengan cairan perasan $N$. benthamiana sehat untuk menghindari terjadinya reaksi silang. Daun $N$. benthamiana sehat digerus dalam larutan PBST dengan perbandingan 1:20 (b/v), sehingga diperoleh cairan perasan tanaman. Antiserum dicampur dengan cairan perasan tanaman tersebut degan perbandingan $1: 1$, digoyang dengan shaker kemudian diinkubasikan pada suhu $37^{\circ} \mathrm{C}$ selama 2 jam, dan pada suhu $4^{\circ} \mathrm{C}$ selama $1 \mathrm{jam}$. Campuran disentrifugasi pada 
$3000 \mathrm{rpm}$ (rotor TMA-5, Tomy) selama 15 menit, supernatan diambil dan disimpan dalam suhu $4{ }^{\circ} \mathrm{C}$ selama 6 jam. Selanjutnya larutan disentrifugasi pada $3000 \mathrm{rpm}$ (rotor TMA-5, Tomy) selama 15 menit. Supernatan diambil dan siap digunakan untuk uji serologi.

Isolasi Gamma-globulin. Antiserum yang dihasilkan dimurnikan menggunakan metode presipitasi dengan amonium sulfat jenuh menurut metode Clarck \& Adams (1977). Antiserum $1 \mathrm{ml}$ diencerkan dengan $9 \mathrm{ml}$ akuades, kemudian ditambah $10 \mathrm{ml}$ amonium sulfat jenuh secara perlahan. Setelah diinkubasi selama 30 menit kemudian disentrifugasi pada $3000 \mathrm{rpm}$ (rotor TMA-5, Tomy) selama 15 menit. Hasil presipitat ditambah $2 \mathrm{ml}$ PBS $0,01 \mathrm{M}, \mathrm{pH} \mathrm{7,4}$ yang mengandung sodium azide $0,01 \%$. Campuran kemudian didialisis dalam $500 \mathrm{ml}$ PBS $0,01 \mathrm{M}$, pH 7,4 pada suhu $4^{\circ} \mathrm{C}$ dengan 3 kali penggantian larutan penyangga setiap 8 jam.

Kajian Serologi. Reaktivitas antiserum yang dihasilkan dikaji dengan uji serologi I-ELISA dan TBIA, serta spesifisitasnya diamati pada analisis Western blot dan ISEM.

I-ELISA. Metode I-ELISA dilakukan berdasarkan metode Stack \& Macmillan (2005). Sampel tanaman terinfeksi CVB digerus dalam sample extraction buffer dengan perbandingan 1:5 (b/v). Sampel tersebut dimasukkan ke dalam masing-masing sumuran pada plat mikrotiter ELISA sebanyak $100 \mu 1$ dan diinkubasi pada suhu $4{ }^{\circ} \mathrm{C}$ selama semalam. Selanjutnya masing-masing sumuran plat mikrotiter dicuci sebanyak 6 kali dengan PBST. Sumuran plat mikrotiter diisi dengan $100 \mu 1$ antiserum yang telah dilarutkan dalam bufer ECI $(0,2 \mathrm{~g}$ bovine serum albumin, $2 \mathrm{~g}$ polyvinylpyrrolidone, 0,02 $\mathrm{g}$ sodium azide dan dilarutkan dalam $100 \mathrm{ml}$ PBST, $\mathrm{pH}$ $7,4)$ dan kemudian diinkubasi pada suhu $37^{\circ} \mathrm{C}$ selama 2 jam. Masing-masing sumuran dicuci kembali dengan PBST dan diisi $100 \mu 1$ konjugat (anti guinea pig-IgG, Sigma Chemical Co. St. Louise, USA) yang dilarutkan dalam bufer ECI (1:1000) dan diinkubasi pada suhu ruang selama 2 jam. Sumuran plat mikrotiter dicuci dengan PBST, kemudian diisi dengan $100 \mu 1$ substrat PNP yang dilarutkan dalam bufer PNP. Setelah diinkubasi pada suhu ruang selama 30 menit dilakukan pengamatan secara kuantitatif dengan menggunakan ELISA reader pada panjang gelombang $405 \mathrm{~nm}$. Reaksi dihentikan dengan cara menambahkan larutan $\mathrm{NaOH} 3 \mathrm{M}$ sebanyak $50 \mu 1$ ke dalam masing-masing sumuran. Kontrol negatif yang digunakan adalah tanaman sehat dan bufer.
TBIA. Pengujian TBIA dilakukan berdasarkan metode Lin et al. (1990). Sampel daun dipotong melintang pada bagian pangkal daun yang masih putih dan dibuat tepi potongan yang rata. Potongan ini kemudian ditempelkan pada membran nitroselulosa (Amersham Hybond-P PVDF membrane, GE Health Care, UK) selama 1 menit. Sebelumnya membran diperlakukan dengan dicelup pada metanol absolut selama 10 detik, kemudian dicuci masing-masing 5 menit di dalam akuabides dan phosphate buffer saline (PBS) $(137 \mathrm{mM} \mathrm{NaCl}, 1,5$ $\mathrm{mM} \mathrm{KH} \mathrm{PO}_{4}, 8,0 \mathrm{mM} \mathrm{Na}_{2} \mathrm{HPO}_{4}, 2,7 \mathrm{mM} \mathrm{KCl}, 3,0 \mathrm{mM}$ $\mathrm{NaN}_{3}, \mathrm{pH} 7,4$ ) dan dikeringanginkan di atas kertas saring yang telah dicelup ke dalam PBS. Membran yang telah diblot ditempatkan dalam wadah plastik dan diblocking dengan susu skim 2\% (w/v) yang dilarutkan dalam PBS selama 60 menit pada suhu ruang. Membran diinkubasikan dengan antiserum pada suhu ruang selama 1-2 jam, atau pada suhu $4{ }^{\circ} \mathrm{C}$ semalam. Antiserum diencerkan dalam PBS dengan seri pengenceran sesuai perlakuan. Membran dicuci dengan PBST selama 10 menit sebanyak 3 kali pada suhu ruang. Membran kemudian diinkubasikan dengan konjugat pada pengenceran 1:1000 dalam PBS selama 2-3 jam pada suhu ruang. Membran dicuci sebagaimana di atas, dan diwarnai dengan substrat 5-bromo-4-chloro-3-indolyl phosphate/nitro blue tetrazolium (BCIP/NBT) (Sigma Chemical Co., USA) dalam bufer alkaline phosphate (AP) $(0,1 \mathrm{M}$ Tris Base, $0,1 \mathrm{M} \mathrm{NaCl}, 5,0 \mathrm{mM}$ $\left.\mathrm{MgCl}_{2} \cdot 6 \mathrm{H}_{2} \mathrm{O}, \mathrm{pH} 9,5\right)$. Reaksi positif ditunjukkan dengan perubahan warna ungu pada tissue blot. Reaksi pewarnaan dihentikan dengan mencuci membran dengan akuabides dan dikeringanginkan.

Analisis Western blot. Pengujian Western blot dilakukan berdasarkan metode Towbin et al. (1979). Siapan suspensi virus murni, protein tanaman yang terinfeksi CVB dan tanaman sehat dielektroforesis pada $10 \%$ gel SDS-PAGE, kemudian ditransfer ke membran nitroselulosa (Amersham Hybond-P PVDF membrane, GE Health Care, UK). Membran diinkubasi dalam antiserum dengan pengenceran 1:500 dalam tris buffer saline (TBS) $(50 \mathrm{mM}$ Tris- $\mathrm{HCl}, 50 \mathrm{mM} \mathrm{NaCl}, \mathrm{pH} 7,5)$ selama 1-2 jam. Membran dicuci dengan TBST (TBS $+0,5 \%$ Tween 20) selama 10 menit sebanyak 3 kali. Setelah pencucian, membran diinkubasi dalam konjugat alkaline phosphatase (Sigma Chemical Co., USA) pada pengenceran 1:1000 dalam TBS selama 2-3 jam. Kemudian dilakukan pencucian sebagaimana di atas, dan diwarnai dengan substrat BCIP/NBT (Sigma Chemical Co.,USA). Semua tahapan pengujian ini dilakukan pada 
suhu ruang. Reaksi positif ditunjukkan dengan perubahan warna ungu pada membran. Reaksi pewarnaan dihentikan dengan mencuci membran dengan akuabides dan dikeringanginkan.

ISEM. Teknik ISEM dilakukan berdasarkan metode Dykstra (1992). Satu tetes suspensi antiserum diteteskan pada cawan Petri yang sudah dilapisi membran parafilm. Grid yang sudah dilapisi colodion dan dikarbonisasi diletakkan secara perlahan pada tetesan suspensi antiserum. Bagian grid yang terlapisi dibuat menempel pada suspensi dan diinkubasi selama 30 menit pada suhu $25^{\circ} \mathrm{C}$. Grid dicuci dengan sepuluh tetes PBS. Siapan virus murni diteteskan pada bagian lain di atas parafilm dan grid diletakan pada tetesan siapan virus murni tersebut, kemudian diinkubasikan selama 15 menit. Grid dicuci sebagaimana pencucian sebelumnya. Grid dikeringkan, dan segera setelah itu bagian grid yang terlapisi diletakkan pada cairan pewarna. Grid dikeringkan dengan kertas saring dan diamati dengan mikroskop elektron transmisi model JEOL 1010 yang dioperasikan pada $80 \mathrm{kV}$. Siapan virus murni tanpa didekorasi dengan antiserum dipakai sebagai kontrol.

\section{HASIL DAN PEMBAHASAN}

\section{Kualitas Antiserum}

Konsentrasi antiserum. Antiserum diproduksi dengan melakukan imunisasi terhadap marmut yaitu dengan menginjeksikan siapan virus murni CVB ke dalam tubuh marmut. Masing-masing marmut menghasilkan antiserum rata-rata $10,75 \mathrm{ml}$. Nilai absorbansi pada panjang gelombang $280 \mathrm{~nm}$ dari antiserum tidak diserap, antiserum yang sudah diserap menggunakan cairan perasan $N$. benthamiana serta antiserum murni (gamma globulin) berturut-turut 1,569;0,938 dan 0,667. Berdasarkan asumsi bahwa nilai absorbansi 1,4 pada panjang gelombang $280 \mathrm{~nm}$ setara dengan konsentrasi $1 \mathrm{mg} / \mathrm{ml}$, maka dapat dihitung konsentrasi antiserum kasar, antiserum yang diserap dan antiserum murni berturut-turut $1,121 \mathrm{mg} / \mathrm{ml} ; 0,670 \mathrm{mg} / \mathrm{ml}$ dan $0,476 \mathrm{mg} /$ $\mathrm{ml}$. Konsentrasi protein antiserum murni yang dipresipitasi menggunakan amonium sulfat lebih kecil dibandingkan dengan antiserum yang tidak diserap maupun yang diserap. Namun demikian, reaktivitasnya terhadap antigen paling tinggi dibandingkan dengan antiserum lainnya. Menggunakan antiserum murni yang sudah dipisahkan dari protein lain yang terdapat dalam suatu antiserum dapat meningkatkan akurasi dan spesifitasnya dalam uji serologi.
Titer antiserum. Titer antiserum ditentukan dengan metode ELISA yaitu melalui pengujian beberapa perlakuan pengenceran antiserum $(100,500,1000,5000$, $10.000,50.000,100.000,500.000$ dan 1.000 .000 kali). Hasil yang diperoleh menunjukkan bahwa antiserum yang tidak diserap maupun yang diserap mempunyai titer 1/50.000, sedangkan antiserum murni mempunyai titer 1/100.000 (Gambar 1).

Titer antiserum untuk serum tidak diserap dan diserap yang diproduksi pada penelitian ini sedikit lebih tinggi dibandingkan dengan kelompok virus lain. Penelitian Sulandari et al. (2004) pada produksi antiserum geminivirus mendapatkan bahwa antiserum yang tidak diserap maupun yang diserap mempunyai titer $1 / 10.000$, dan gamma globulin mempunyai titer 1/100.000; sedangkan produksi antiserum geminivirus yang dilakukan Haryadi (2006) menemukan titer antiserum yaitu $1 / 16.384$. Titer antiserum antara lain dipengaruhi oleh jenis virus dan hewan percobaan yang dipakai dalam produksi antiserum. Makin besar berat molekul antigen, makin efektif berperan sebagai zat imunogen untuk menstimulasi antiserum (Hull, 2002). Kemungkinan CVB yang memiliki berat molekul protein selubung $34 \mathrm{kDa}$ lebih imunogenik dibandingkan dengan geminivirus pada penelitian Sulandari et al. (2004) yang memiliki berat molekul protein selubung $29 \mathrm{kDa}$, sehingga CVB menstimulasi antiserum dengan titer yang relatif lebih tinggi. Di samping itu, marmut yang dipakai sebagai hewan percobaan dalam produksi antiserum ini menghasilkan antiserum berkualitas baik. Menurut Rollin \& Kesel (1995), marmut adalah sumber komplemen serum yang sangat baik; dan sering menjadi hewan pilihan dalam produksi antiserum karena hanya memerlukan sedikit antigen untuk imunisasi, volume serumnya relatif banyak, mudah pemeliharaannya, dan menghasilkan antiserum yang baik kualitasnya.

\section{Uji Serologi}

Analisis Western blot. Antiserum yang diproduksi pada penelitian ini juga diuji untuk analisis Western blot, untuk melihat spesifisitas reaksi antiserum dengan protein selubung CVB. Menggunakan antiserum yang sudah dimurnikan dapat mendeteksi adanya pita dengan ukuran sekitar $34 \mathrm{kDa}$ (Gambar 2B) sesuai dengan ukuran protein selubung yang didapatkan pada uji SDS-PAGE (Gambar 2A). Antiserum dengan pengenceran 1:1000 mampu mengkonfirmasi protein selubung CVB pada uji ini. Protein $34 \mathrm{kDa}$ yang terdeteksi pada analisis Western blot sesuai dengan berat molekul protein selubung CVB yang digunakan untuk imunisasi pada hewan percobaan. 


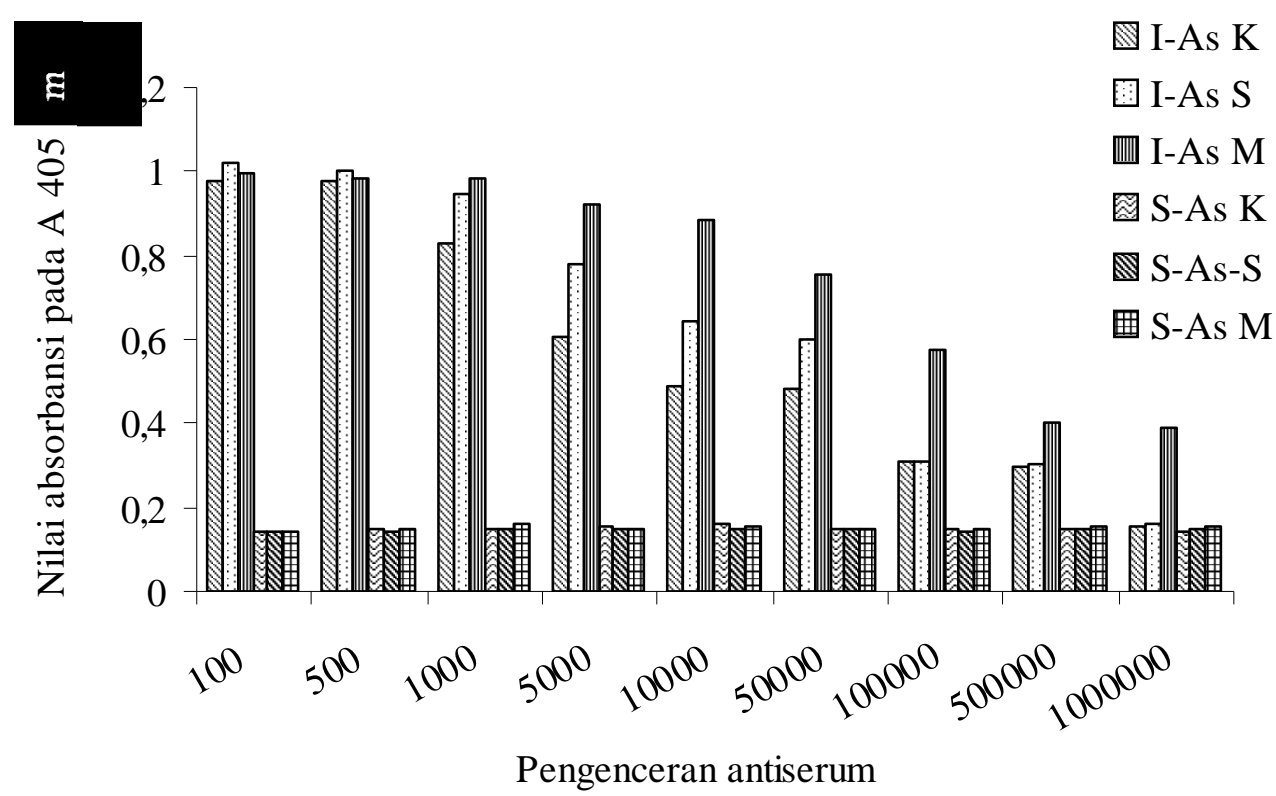

Gambar 1. Titer antiserum tidak diserap (As K), antiserum diserap (As S) dan antiserum murni (As M) berdasarkan ELISA. I : sampel tanaman terinfeksi CVB. S : sampel tanaman sehat

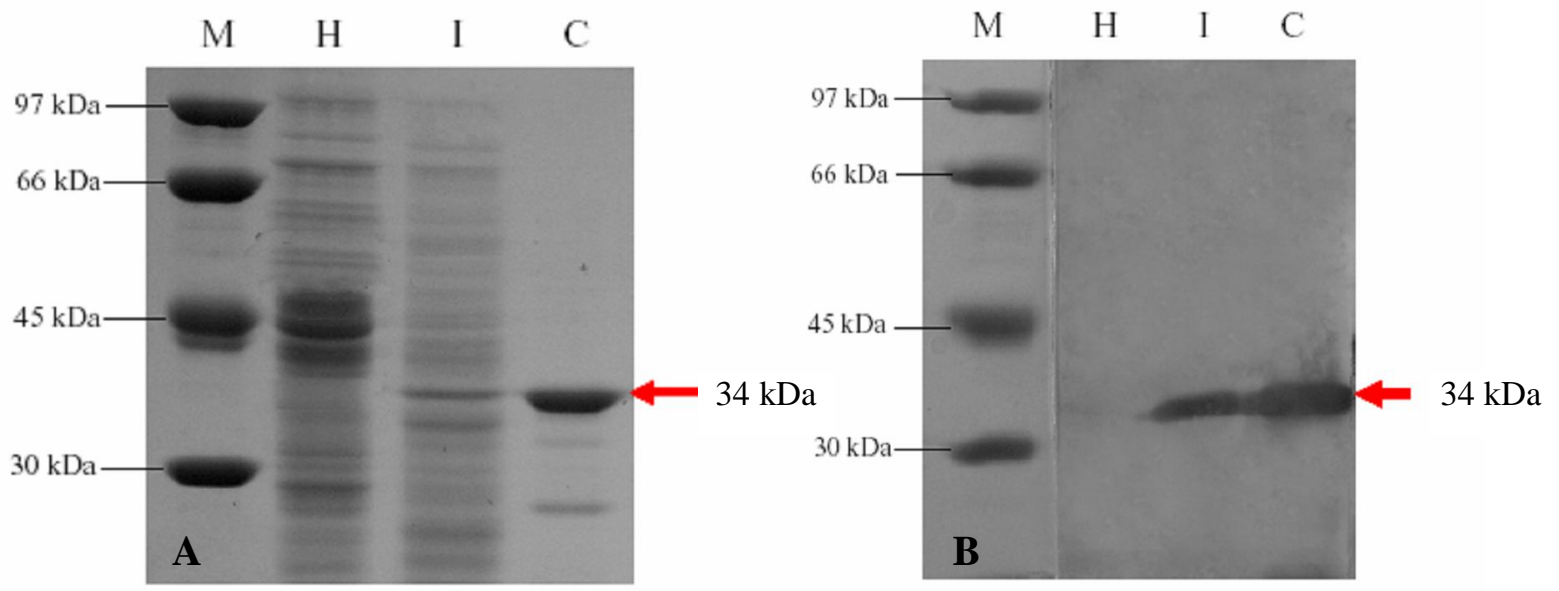

Gambar 2. Hasil analisis SDS-PAGE (A) dan Western blot (B) protein selubung CVB menggunakan antiserum yang diproduksi. $\mathrm{M}$ : Marker. $\mathrm{H}$ : daun $N$. benthamiana sehat. I : daun $N$. benthamiana terinfeksi CVB. C : virus murni 
Hal ini membuktikan bahwa antiserum yang dihasilkan berasal dari virus murni yang digunakan sebagai imunogen dan bukan dari antigen lain. Analisis Western blot juga membuktikan tidak adanya background atau reaksi positif antiserum terhadap komponen tanaman. Ini dapat dilihat dari bersihnya lajur sampel daun tanaman $N$. benthamiana sehat.

ISEM. Pengamatan partikel CVB pada mikroskop elektron dengan metode ISEM menggunakan antiserum yang diproduksi pada penelitian ini memberikan hasil dekorasi yang baik. Partikel virus berbentuk panjang agak lentur nampak lebih jelas pada grid yang sebelumnya dicelupkan pada suspensi antiserum dibandingkan dengan siapan murni tanpa antiserum (Gambar 3). Hal ini menunjukkan bahwa antiserum yang dihasilkan memberikan reaksi yang spesifik terhadap protein selubung virus.

I-ELISA. Mengamati reaktivitas antiserum pada pengujian secara I-ELISA, dibuat pengenceran antiserum 100, 500, 1000, 5000, 10.000, 50.000, 100.000, 500.000 dan 1.000 .000 kali dan pengenceran cairan perasan tanaman terinfeksi : bufer (b/v) yaitu $1 / 2,1 / 4,1 / 8$, $1 / 16,1 / 32,1 / 64,1 / 128,1 / 256$ dan 1/512. Uji serologi dengan ELISA menunjukkan bahwa semakin tinggi pengenceran antiserum semakin lemah reaksi yang terjadi, atau semakin kecil nilai nisbah absorbansi pada sampel dengan nilai absorbansi pada kontrol negatif. Demikian pula semakin tinggi pengenceran sampel menunjukkan reaksi yang semakin lemah. Sensitifitas ELISA dalam mendeteksi CVB cukup tinggi dan virus masih terdeteksi pada pengenceran cairan perasan tanaman terinfeksi $1 / 256$. Pengenceran sampel cairan perasan tanaman terinfeksi 1/16 menunjukkan reaksi yang kuat sampai pada pengenceran antiserum 1000 kali dan masih menunjukkan reaksi positif sampai pengenceran antiserum 100.000 kali (Tabel 1).

TBIA. Pada uji serologi TBIA dibuat pengenceran antiserum 100, 500, 1000, 5000, 10.000, 50.000, 100.000,

Tabel 1. Reaksi antiserum terhadap cairan perasan tanaman terinfeksi CVB pada berbagai seri pengenceran melalui metode I-ELISA

\begin{tabular}{|c|c|c|c|c|c|c|c|c|c|c|c|}
\hline \multirow{3}{*}{$\begin{array}{l}\text { Pengenceran } \\
\text { antiserum }\end{array}$} & \multicolumn{11}{|c|}{ Reaksi antiserum terhadap sampel } \\
\hline & \multirow{2}{*}{ Bufer } & \multirow{2}{*}{$\begin{array}{c}\text { Tanaman } \\
\text { Sehat* }\end{array}$} & \multicolumn{9}{|c|}{ Pengenceran cairan perasan tanaman terinfeksi CVB** } \\
\hline & & & $1 / 2$ & $1 / 4$ & $1 / 8$ & $1 / 16$ & $1 / 32$ & $1 / 64$ & $1 / 128$ & $1 / 256$ & $1 / 512$ \\
\hline 100 & - & - & +++ & +++ & +++ & +++ & +++ & +++ & ++ & + & - \\
\hline 500 & - & - & +++ & +++ & +++ & +++ & +++ & ++ & ++ & + & - \\
\hline 1000 & - & - & +++ & +++ & +++ & +++ & ++ & + & + & + & - \\
\hline 5000 & - & - & +++ & +++ & +++ & ++ & + & + & + & + & - \\
\hline 10.000 & - & - & +++ & +++ & ++ & + & - & + & - & - & - \\
\hline 50.000 & - & - & ++ & ++ & ++ & + & - & - & - & - & - \\
\hline 100.000 & - & - & ++ & ++ & + & + & - & - & - & - & - \\
\hline 500.000 & - & - & + & + & + & - & - & - & - & - & - \\
\hline 1.000 .000 & - & - & - & - & - & - & - & - & - & - & - \\
\hline
\end{tabular}

Keterangan :

Reaksi positif jika nilai absorbansi (405 nm) 3 kali nilai kontrol negatif (Verma et al. 2003).

* Tanaman krisan sehat sebagai kontrol negatif

** Tanaman krisan terinfeksi CVB isolat Cianjur

$+++\quad$ Reaksi kuat bila nilai absorbansi $\geq 6$ kali nilai kontrol negatif

$++\quad$ Reaksi sedang bila nilai absorbansi $(4,5<\oplus<6)$ kali nilai kontrol negatif

$+\quad$ Reaksi lemah bila nilai absorbansi $\leq 4,5$ atau $\geq 3$ kali nilai kontrol negatif

- $\quad$ Reaksi negatif 


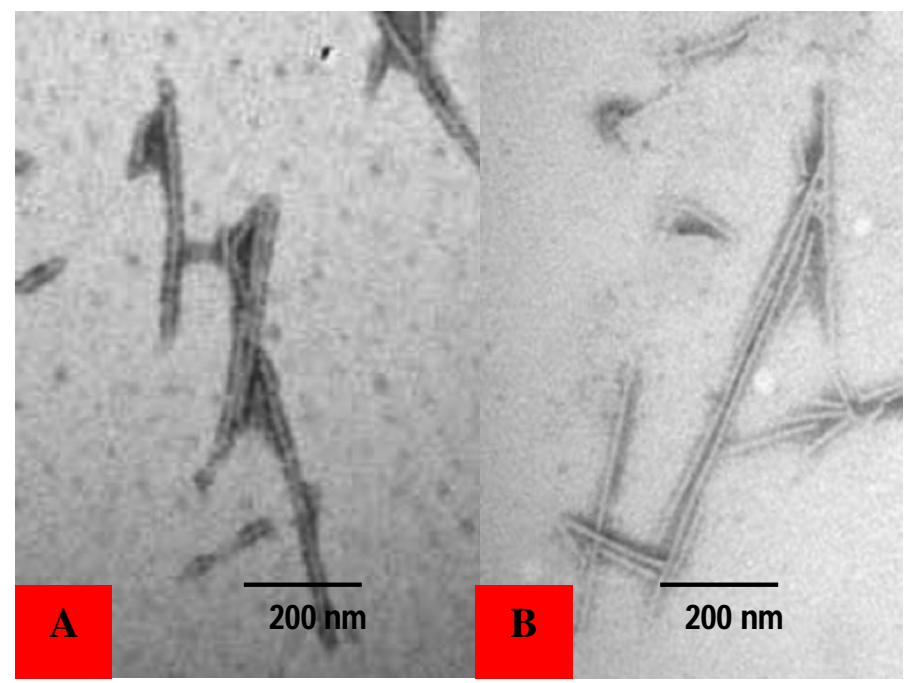

Gambar 3. Partikel CVB pada pengamatan dengan mikroskop elektron (pembesaran 40.000 kali). Partikel virus berbentuk panjang agak lentur nampak lebih jelas pada siapan virus murni didekorasi dengan antiserum (A), dibandingkan dengan siapan virus murni tanpa antiserum (B)

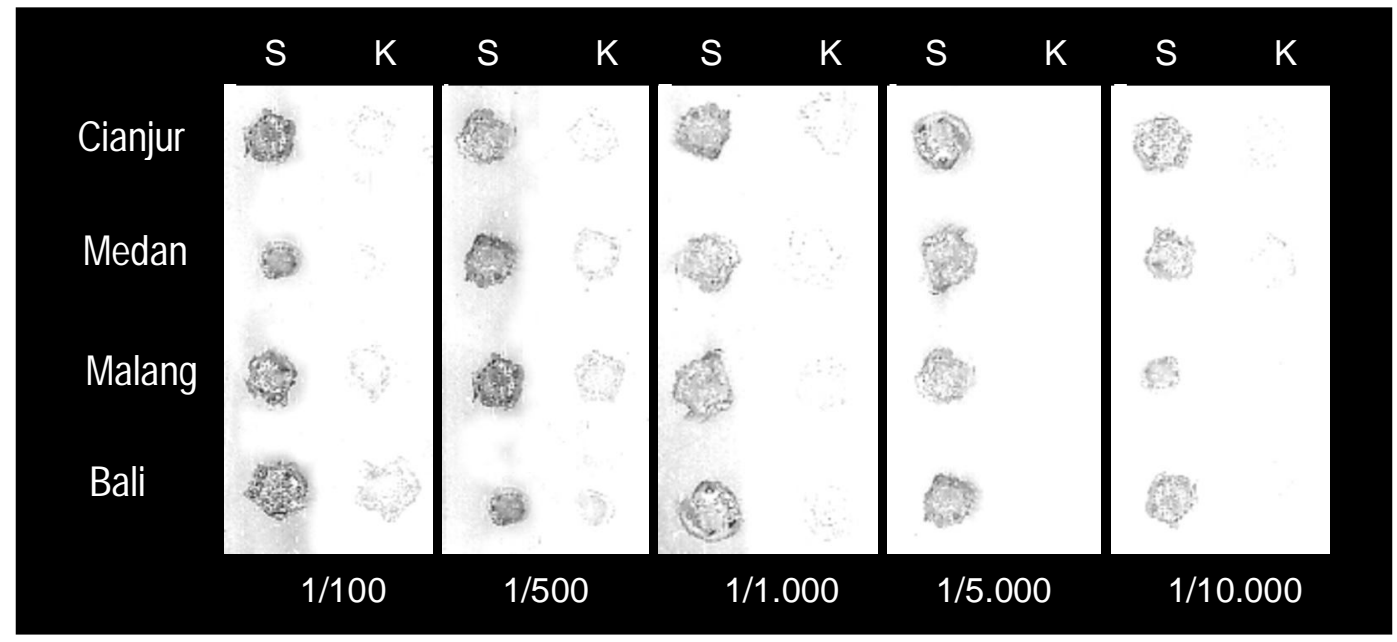

Gambar 4. Reaktivitas antiserum pada pengenceran 1/100, 1/500, 1/1000, 1/5000 dan 1/ 10.000 terhadap isolat CVB dari berbagai lokasi pada uji serologi dengan TBIA. $\mathrm{S}$ : sampel terinfeksi; $\mathrm{K}$ : kontrol negatif 
500.000 dan 1.000 .000 kali. Hasil pengujian menunjukkan bahwa TBIA terbukti cukup sensitif untuk mendeteksi keberadaan CVB pada tanaman krisan. Reaksi positif pada pengujian TBIA, yang ditunjukkan dengan perubahan warna ungu pada tissue blot setelah pemberian substrat BCIP/NBT, masih nampak pada pengenceran antiserum 10.000 kali (Gambar 4).

Sampel tanaman sehat (kontrol) bersih, menandakan kespesifikan antiserum terhadap CVB. Melalui TBIA juga diketahui bahwa antiserum yang dihasilkan dapat mengidentifikasi CVB yang menginfeksi krisan dari berbagai lokasi (Cianjur, Medan, Malang dan Bali). Reaktivitas antiserum ternyata sama terhadap sampel yang berasal dari berbagai lokasi yang berbeda. Reaktivitas yang sama pada isolat yang berbeda tersebut disebabkan keempat isolat memiliki hubungan yang sangat dekat dengan susunan asam amino protein selubung yang memiliki tingkat homologi tinggi (95-99\%) (Temaja, 2008). Di samping itu antiserum yang digunakan dalam pengujian adalah antiserum poliklonal sehingga mampu mengenali berbagai epitop dari protein selubung virus. Jenis epitop yang ada sangat dipengaruhi oleh jenis protein yang tersusun dari beberapa macam asam amino. Gen penyandi protein selubung dari genus carlavirus diketahui mempunyai runutan susunan DNA dengan derajat kesamaan yang tinggi (conserved) antar anggotanya.

Uji serologi secara TBIA lebih menguntungkan dibandingkan dengan teknik ELISA. Metode TBIA lebih mudah dan cepat, biayanya lebih murah karena hanya diperlukan reagen yang lebih sedikit dan dapat menguji sampel lebih banyak. Pada selembar membran nitroselulosa yang berukuran $7 \mathrm{~cm} \mathrm{x} 4 \mathrm{~cm}$ dapat menampung 96 sampel, dengan jarak antar sampel sekitar $5 \mathrm{~mm}$. Hal ini penting untuk deteksi massal terhadap bahan tanaman krisan terinfeksi CVB, terutama pada perusahaan eksportir bahan tanaman krisan dan Karantina Tumbuhan dalam kaitannya dengan sertifikasi bahan tanaman krisan bebas virus yang memerlukan pengujian sampel dalam jumlah besar. Pengujian secara massal sampel dapat mengurangi pengeluaran untuk pengujian karena lebih efisien memanfaatkan reagen dan di samping itu dapat dikerjakan lebih cepat. Metode ini juga memungkinkan penyiapan (blotting) sampel dilakukan di lapangan, kemudian membran disimpan beberapa hari untuk proses selanjutnya di laboratorium.

\section{SIMPULAN}

Imunisasi marmut menggunakan $150 \mu \mathrm{g}$ CVB murni dapat menghasilkan antiserum yang cukup baik kualitasnya. Teknik I- ELISA dan TBIA sangat potensial untuk digunakan sebagai alat deteksi CVB karena sinsitifitasnya cukup tinggi. Pengujian sampel dengan jumlah besar lebih menguntungkan menggunakan metode TBIA. TBIA juga memungkinkan blotting sampel dilakukan di lapangan, kemudian membran disimpan untuk proses selanjutnya di laboratorium.

\section{DAFTAR PUSTAKA}

Agrios GN. 1997. Plant Pathology. 4thed. California : Academic Press, Inc.

Clark MF \& Adams AN. 1977. Characteristics of the Microplate Method of Enzyme-Linked Immunosorbent Assay for the Detection of Plant Viruses. J. Virol. Methods 34: 475-483.

Crowter JR. 1995. ELISA: Theory and Practice. New Jersey : Humana Press Inc.

Dijkstra J \& de Jager CP. 1998. Pratical Plant Virology. Protocol and Exercises. New York: Springer-Verlag Berlin Heidelberg.

Dykstra MJ. 1992. Biological Electron Mycroscopy: Theory, Techniques and Troubleshooting. London : Plenum Press.

Flegler SL, Heckman Jr. JW \& Klomparens KL. 1993. Scanning and Transmission Electron Microscopy: An Introduction. New York : Oxford Univ. Press.

Foster GD. 1998. Carlavirus isolation and RNA extraction. Pp. 145-150. In: Foster GD \& Taylor SC, eds. Plant Virology Protocols, from Virus Isolation to Transgenic Resistance. Totowa : Humans Press.

Hampton R, Ball E \& de Boer S. 1990. Serological Methods for Detection and Identification of Viral and Bacterial Plant Pathogens. USA : American Phytopathological Society Press.

Harlow \& Lane D. 1999. Using Antibodies. A Laboratorium Manual. New York : Cold Springer Harbor Laboratory Press. 
Haryadi D. 2006. Produksi Antibodi Poliklonal Geminivirus Penyebab Penyakitdaun Keriting Kuning Cabai, dan Kajian Serologinya. Tesis. Sekolah Pascasarjana IPB. Bogor.

Hollings M \& Stone OM. 1972. Chrysanthemum Virus B. CMI/AAB Description of Plant Viruses No. 110.

Hull R. 2002. Matthews' Plant Virology. Fourth Ed. San Diego : Academic Press.

Kumari SG, Makkouk KM \& Attar N. 2006. An Improved Antiserum for Sensitive Serologic Detection of Chickpea chlorotic dwarf virus. J. Phytopathology 154: 129-133.

Lin NS, Hsu YH \& Hsu HT. 1990. Immunological Detection of Plant Viruses and A Mycoplasmalike Organism by Direct Tissue Blotting on Nitrocellulose Membranes. Phytopathology 80: 824-828.

Mahmood T, Hein GL \& French RC. 1997. Development of Serological Procedures for Rapid and Reliable Detection of Wheat Streak Mosaic Virus in A Single Wheat Curl Mite. Plant Dis. 81: 250-253.

Rollin BE \& Kesel ML. 1995. The Experimental Animal in Biomedical Research. Vol.II. Care, Husbandry and Well-being An Overview by Species. London: CRC Press Inc.

Stack \& Macmillan. 2005. Brycella Serology. Brunet Publication. FAO/WHO Collaborating Centre for Reference and Research on Brucellosis,
Central Veterinary Laboratory, New Haw, Addlestone, Surrey Kt15 3NB, United Kingdom. http://www.moag.gov. ilbrunetpublic_sub4_p1.html [20 Des 2006].

Sulandari S, Suseno R, Hidayat SH, Sosromarsono S \& Harjosudarmo J. 2004. Pembuatan Antiserum dan Kajian Serologi Virus Penyebab Penyakit Daun Keriting Kuning Cabai. J. Perlind. Tan. Ind. 10(1): 42-52.

Temaja IGRM. 2008. Chrysanthemum B Carlavirus (CVB) yang Menginfeksi Krisan di Indonesia: Karakterisasi dan Pengembangan Metode Deteksi. Disertasi. Sekolah Pascasarjana IPB. Bogor.

Towbin H, Staehelin T \& Gordon J. 1979. Electrophoretic Transfer of Protein from Polyacrylamide Gels to Nitrocellulose Sheets: Procedure and Some Applications. Proc. Natl. Acad. Sci. USA 76: 4350-4354.

Verma N, Sharma A, Ram R, Hallan V, Zaidi AA \& Garg ID. 2003. Detection, Identification and Incidence of Chrysanthemum B Carlavirus in Chrysanthemum in India. Crop Protect. 22: 415-429. 